\title{
Synthesis of gold(III) complexes of 2-(diphenylthiophosphino)aniline
}

\author{
Eduardo J. Fernándeza, Emma García-Luzuriagaa ${ }^{a}$, Antonio Laguna ${ }^{b}$, \\ José M. López-de-Luzuriaga ${ }^{a}$ and M. Elena Olmos ${ }^{a^{*}}$ \\ www.goldbulletin.org \\ Published online from 7 April 2010
}

The gold(III) complex $\left[\mathrm{Au}\left(\mathrm{C}_{6} \mathrm{~F}_{5}\right)_{2}\left(\mathrm{SPNH}_{2}\right)\right] \mathrm{ClO}_{4}$ (1) containing the $\mathrm{S}, \mathrm{N}$-donor ligand 2-(diphenylthiop hosphino)aniline $\left(\mathrm{S}=\mathrm{PNH}_{2}\right.$ ) can be easily prepared by treatment of $\mathrm{S}=\mathrm{PNH}_{2}$ with $\left[\mathrm{Au}\left(\mathrm{C}_{6} \mathrm{~F}_{5}\right)_{2}\left(\mathrm{OEt}_{2}\right)_{2}\right] \mathrm{ClO}_{4}$ and deprotonated with PPN(acac) to afford $\left[\mathrm{Au}\left(\mathrm{C}_{6} \mathrm{~F}_{5}\right)_{2}(\mathrm{SPNH})\right]$ (2). Complex 2 can also be obtained in a one-step reaction from $\mathrm{SPNH}_{2}$ and $\left[\mathrm{Au}\left(\mathrm{C}_{6} \mathrm{~F}_{5}\right)_{2}(\mathrm{acac})\right]$. The electronic density in excess in 2 can be employed to incorporate a new metallic fragment to give the mixed complexes $\left[\mathrm{Au}\left(\mathrm{C}_{6} \mathrm{~F}_{5}\right)_{2}\left\{\mathrm{SPNH}\left(\mathrm{MPPh}_{3}\right)\right\}\right] \mathrm{ClO}_{4}(\mathrm{M}=\mathrm{Au}(3), \mathrm{Ag}$ (4)). The crystal structures of 1 and 2 have been determined by X-ray diffraction, showing that the electronic density in excess in complex 2 is located in the Au-N-C fragment.

\footnotetext{
a Departamento de Química, Universidad de La Rioja, Grupo de Síntesis Química de La Rioja, U.A.-CSIC. Madre de Dios 51, E-26006 Logroño, Spain

- Departamento de Química Inorgánica, Instituto de Ciencia de Materiales de Aragón, Universidad de Zaragoza-CSIC,

E-50009 Zaragoza, Spain
}

* Corresponding author: M. Elena Olmos

\section{Introduction}

It is well known that polyfunctional ligands with P-, S-, N- or C- donor atoms are often employed in the synthesis of polynuclear complexes. In the case of gold, such species may present a number of interesting applications, including chemotherapy, diagnostics, electron microscopy, catalysis and surface technology, ${ }^{1-5}$ and some gold compounds containing $\mathrm{S}, \mathrm{N}$ - or $\mathrm{C}, \mathrm{N}$ - amidate ligands have been described in the last few years. 6,7 In the particular case of the P,N-donor ligand 2-(diphenylphosphino) aniline $\left(\mathrm{PNH}_{2}\right)$, a series of derivatives of a large number of transition metals have been synthesized, most of them containing $\mathrm{PNH}_{2}$ as bidentate chelating ligand and the nitrogen center is sometimes deprotonated. ${ }^{8-16}$ and references therein However, only a few examples of group 11 metal complexes containing this ligand have been reported ${ }^{17}$ with the metal centre invariably in the oxidation state +1 , with the unique exceptions of the $\mathrm{Cu}(\mathrm{II})$ derivative $\left[\mathrm{Cu}\left(\mathrm{PNH}_{2}\right)_{2}\right]\left(\mathrm{BF}_{4}\right)_{2}{ }^{14 \mathrm{~d}}$ and some $\mathrm{Au}(\mathrm{III})$ derivatives described by us some years ago. ${ }^{18}$ However, as far as we know, complexes containing the oxide or sulfide of 2-(diphenylphosphino)aniline are still unknown, and a scarce number of gold complexes containing $\mathrm{S}, \mathrm{N}$-donor ligands have been described, ${ }^{19}$ most of them being gold(III) compounds containing bi- or tri-dentate chelating ligands. ${ }^{19 a-h}$ In the case of the gold $(I)$ derivatives of the related ligand 2-(diphenylthiophosphino) pyridine ${ }^{191}$ the bidentate ligand binds gold only through the sulfur atom, thus acting as monodentate, or acts as bidentate bridging ligand in dinuclear compounds.

In this paper we describe the synthesis and characterization of some gold(III) derivatives containing the $\mathrm{S}, \mathrm{N}$-donor ligand 2-(diphenylthioph osphino)aniline $\left(\mathrm{S}=\mathrm{PNH}_{2}\right)$ or its deprotonated form $(\mathrm{S}=\mathrm{PNH})$ as well as a couple of $\mathrm{Au}^{\prime \prime \prime \prime} / \mathrm{Au}^{\prime}$ or $\mathrm{Au} \mathrm{u}^{\prime \prime \prime} / \mathrm{Ag}^{\prime}$ 
complexes of the deprotonated ligand that may

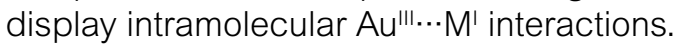

\section{Synthesis and characterization}

Treatment of $\mathrm{S}=\mathrm{PNH}_{2}$ with an equimolecularamount of a freshly prepared solution of $\left[\mathrm{Au}\left(\mathrm{C}_{6} \mathrm{~F}_{5}\right)_{2}\left(\mathrm{OEt}_{2}\right)_{2}\right] \mathrm{ClO}_{4}$ leads to the precipitation of the cationic complex $\left[\mathrm{Au}\left(\mathrm{C}_{6} \mathrm{~F}_{5}\right)_{2}\left(\mathrm{SPNH}_{2}\right)\right] \mathrm{ClO}_{4}(\mathbf{1})$ as a white moisture and air-stable solid in which the $\mathrm{S}, \mathrm{N}$-donor ligand binds the gold centre through both donor atoms. It is soluble in chlorinated solvents and acetone and insoluble in diethyl ether and hexane. It behaves as a uni-univalent electrolyte in acetone solutions and its elemental analysis and spectroscopic properties agree with the proposed stoichiometry. Its IR spectrum displays a band at $\sim 3600(\mathrm{~m}) \mathrm{cm}^{-1}$ from the $\mathrm{NH}_{2}$ group, the characteristic absorptions of the perchlorate anion at 1100 (vs, br) and $622(\mathrm{~m}) \mathrm{cm}^{-1},{ }^{20}$ as well as bands assignable to the perfluorophenyl groups bonded to gold(III). ${ }^{21,22}$ The ${ }^{31} \mathrm{P}\left\{{ }^{1} \mathrm{H}\right\}$ NMR spectrum of $\mathbf{1}$ shows a singlet located at $33.6 \mathrm{ppm}$, which corroborates the coordination of the phosphine sulphide (the signal of the free ligand appears at 39.6 ppm), while in its ${ }^{19} \mathrm{~F}$ NMR spectrum the resonances due to two non equivalent pentafluorophenyl groups with relative intensities 1:1 are observed. The aminic protons of the ligand give rise to a multiplet at 5.55 ppm in its ${ }^{1} \mathrm{H}$ NMR spectrum, and the aromatic protons appear between 6.8 and 8.0 ppm. Finally, the parent peak in the mass spectrum (ES+) of complex 1, located at $\mathrm{m} / \mathrm{z}=840$, corresponds to the molecular cation.
The neutral amido complex $\left[\mathrm{Au}\left(\mathrm{C}_{6} \mathrm{~F}_{5}\right)_{2}(\mathrm{SPNH})\right]$ (2) can be obtained by deprotonation of $\mathbf{1}$ with PPN(acac) (PPN = bis(triphenylphosphino)imino) or by treatment of the free ligand $\mathrm{S}=\mathrm{PNH}_{2}$ with the acetylacetonategold(III) derivative $\left[\mathrm{Au}\left(\mathrm{C}_{6} \mathrm{~F}_{5}\right)_{2}(\mathrm{acac})\right]$ through an alternative pathway (see Scheme 1). This complex is obtained as a stable yellow solid, soluble in most common organic solvents and non soluble in hexane, and behaves as non conductor in acetone solution. Its physical, analytical and spectroscopic properties agree with the proposed stoichiometry. The most significant absorption in the IR spectrum of $\mathbf{2}$, apart from those corresponding to the perfluorophenyl groups, is a band of medium intensity located at $3605 \mathrm{~cm}^{-1}$ arising from the $\mathrm{NH}$ group. The resonance of the phosphorus atom in its ${ }^{31} \mathrm{P}\left\{{ }^{1} \mathrm{H}\right\}$ NMR spectrum $(\delta=30.7 \mathrm{ppm})$ appears at higher field than in complex $\mathbf{1}(\delta=33.6 \mathrm{ppm})$ as a consequence of the deprotonation of the $\mathrm{NH}_{2}$ group. This effect is also shown in its ${ }^{1} \mathrm{H}$ NMR spectrum, where the signal of the $\mathrm{NH}^{-}$is now located at 4.66 ppm (5.55 ppm in 1). The ${ }^{19} \mathrm{~F}$ NMR spectrum of $\mathbf{2}$ is as expected, very similar to that of complex 1 .

The electronic density in excess that the neutral derivative $\mathbf{2}$ displays (mainly located at the nitrogen atom) allowed us to incorporate a second metal centre, and thus complex 2 reacts with equimolecular amounts of $\left[\mathrm{Ag}\left(\mathrm{OClO}_{3}\right)\left(\mathrm{PPh}_{3}\right)\right]$ or with a freshly prepared solution of $\left[\mathrm{Au}\left(\mathrm{OClO}_{3}\right)\left(\mathrm{PPh}_{3}\right)\right]$, leading to the synthesis of the dinuclear complexes $\left[\mathrm{Au}\left(\mathrm{C}_{6} \mathrm{~F}_{5}\right)_{2}\right.$ $\left.\left\{\mathrm{SPNH}\left(\mathrm{MPPh}_{3}\right)\right\}\right] \mathrm{ClO}_{4}(\mathrm{M}=\mathrm{Au}(\mathbf{3}), \mathrm{Ag}(\mathbf{4}))$. Complex $\mathbf{3}$ can also be obtained by direct reaction of $\mathbf{1}$ with

\section{Scheme 1}

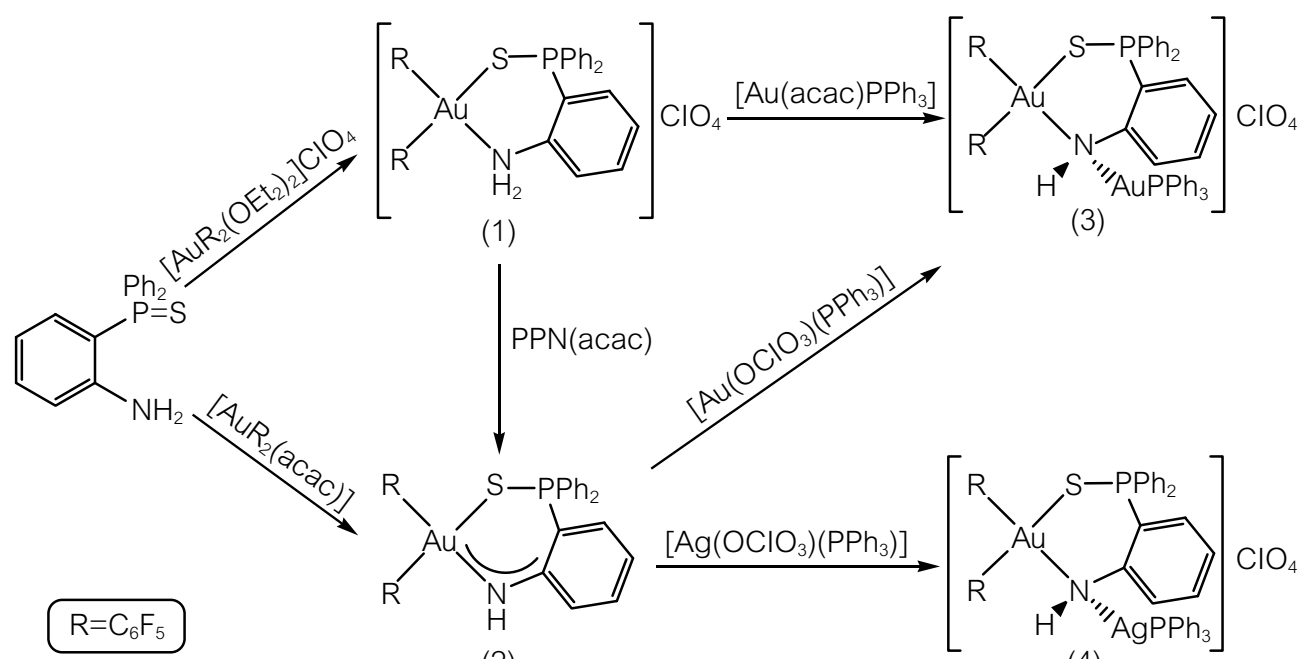

(2)

(4) 
Table 1: Data collection and structure refinement details for complexes $\mathbf{1}$ and $\mathbf{2}$

\begin{tabular}{|c|c|c|}
\hline Compound & $\mathbf{1} \cdot 0.5 \mathrm{CHCl}_{3}$ & 2 \\
\hline Chemical formula & $\mathrm{C}_{30} \mathrm{H}_{16} \mathrm{AuClF}_{10} \mathrm{NO}_{4} \mathrm{PS} \cdot 0.5 \mathrm{CHCl}_{3}$ & $\mathrm{C}_{30} \mathrm{H}_{15} \mathrm{AuF}_{10} \mathrm{NPS}$ \\
\hline Crystal habit & Yellow prism & Yellow plate \\
\hline Crystal size/mm & $0.35 \times 0.2 \times 0.1$ & $0.45 \times 0.4 \times 0.2$ \\
\hline Crystal system & Triclinic & Triclinic \\
\hline Space group & $P-1$ & $P-1$ \\
\hline$a / \AA$ & $10.6399(2)$ & $10.7917(1)$ \\
\hline$b / \AA$ & $12.6135(2)$ & $11.2090(2)$ \\
\hline$c / \AA$ & $13.8554(3)$ & $14.7321(3)$ \\
\hline$\alpha /{ }^{\circ}$ & $74.155(1)$ & $75.763(1)$ \\
\hline$\beta /{ }^{\circ}$ & $88.059(1)$ & $89.459(1)$ \\
\hline$\gamma /{ }^{\circ}$ & $89.076(1)$ & $62.618(1)$ \\
\hline$U / A^{3}$ & $1787.76(6)$ & $1522.63(4)$ \\
\hline Z & 2 & 2 \\
\hline$D c / \mathrm{g} \mathrm{cm}^{-3}$ & 1.857 & 1.831 \\
\hline M & 999.57 & 839.43 \\
\hline$F(000)$ & 962 & 804 \\
\hline$T /{ }^{\circ} \mathrm{C}$ & 20 & -100 \\
\hline $2 \theta \max /{ }^{\circ}$ & 61 & 56 \\
\hline$\mu(\mathrm{Mo}-\mathrm{K} \alpha) / \mathrm{mm}^{-1}$ & 4.493 & 5.035 \\
\hline No. of reflections measured & 19416 & 23892 \\
\hline No. of unique reflections & 8450 & 7196 \\
\hline$R$ int & 0.0400 & 0.0440 \\
\hline$R^{\mathrm{a}}(I>2 \sigma(I))$ & 0.0458 & 0.0296 \\
\hline$w R^{\left.\mathrm{b}_{(} F^{2} \text {, all refl. }\right)}$ & 0.1229 & 0.0821 \\
\hline No. of parameters & 470 & 401 \\
\hline No. of restraints & 158 & 158 \\
\hline$S^{C}$ & 1.066 & 1.076 \\
\hline $\operatorname{Max} . \Delta \rho / \mathrm{e}^{-3}$ & 1.743 & 1.724 \\
\hline \multicolumn{3}{|c|}{ 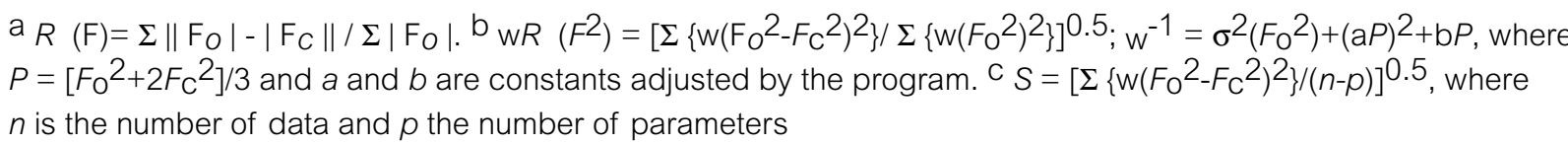 } \\
\hline
\end{tabular}

an equimolecular amount of $\left[\mathrm{Au}(\mathrm{acac})\left(\mathrm{PPh}_{3}\right)\right]$, as shown in Scheme 1, and thus the deprotonation of the amine and the coordination of the metallic fragment occurs in one step. These species are obtained as yellow air- and moisture-stable solids, soluble in chlorinated solvents and acetone and insoluble in diethyl ether and hexane. They behave as uni-univalent electrolytes and their analytical and spectroscopic properties agree with the proposed stoichiometries. Their ${ }^{31} \mathrm{P}\left\{{ }^{1} \mathrm{H}\right\}$ NMR spectra display, besides the singlet assigned to the thiophosphine group at 28.4 (3) or 29.7 (4) ppm, a second resonance from the $\mathrm{PPh}_{3}$ bonded to the new metal center, that appears as a singlet at 28.3 ppm in $\mathbf{3}$.
In the case of the silver species $\mathbf{4}$ this signal appears at room temperature as a wide multiplet that splits into two doublets centered at $13.0 \mathrm{ppm}$ when the spectrum is registered in HDA at $223 \mathrm{~K}$. This pattern is due to the coupling of the phosphorus atom of the triphenylphosphine ligand with both NMR-active isotopomers of silver $\left({ }^{109} \mathrm{Ag}\right.$ and $\left.{ }^{107} \mathrm{Ag}\right)$ with coupling constants of $795.2\left({ }^{109} \mathrm{Ag}-\mathrm{P}\right)$ and $688.7\left({ }^{107} \mathrm{Ag}-\mathrm{P}\right) \mathrm{Hz}$. Regarding their ${ }^{1} \mathrm{H}$ NMR spectra, the resonance of the aminic proton in $\mathbf{3}$ appears at 6.16 ppm, while in 4 it seems to be masked with those corresponding to the aromatic protons. Again, the ${ }^{19} \mathrm{~F}$ NMR spectra of $\mathbf{3}$ and $\mathbf{4}$ confirm the presence of the two types of $\mathrm{C}_{6} \mathrm{~F}_{5}$ groups bonded to gold(III), although in the 


\begin{tabular}{|c|c|c|c|}
\hline $\mathrm{Au}-\mathrm{C}(1)$ & $2.022(6)$ & P-S & $2.023(2)$ \\
\hline$A u-C(11)$ & $2.034(6)$ & $P-C(21)$ & $1.790(6)$ \\
\hline Au-N & $2.157(5)$ & $C(21)-C(26)$ & $1.400(7)$ \\
\hline Au-S & $2.372(2)$ & $\mathrm{C}(26)-\mathrm{N}$ & $1.448(8)$ \\
\hline$C(1)-A u-C(11)$ & 87.2(2) & P-S-Au & $99.01(7)$ \\
\hline$C(1)-A u-N$ & $174.88(19)$ & $C(21)-P-S$ & 109.4(2) \\
\hline C(11)-Au-N & 88.2(2) & $C(26)-C(21)-P$ & $121.4(4)$ \\
\hline C(1)-Au-S & $85.90(16)$ & $C(21)-C(26)-N$ & $121.5(5)$ \\
\hline C(11)-Au-S & $171.54(16)$ & $\mathrm{C}(26)-\mathrm{N}-\mathrm{Au}$ & $121.4(4)$ \\
\hline N-Au-S & $98.86(14)$ & & \\
\hline
\end{tabular}

Table 3: Selected bond lengths $[\AA]$ and angles $\left[{ }^{\circ}\right]$ for complex 2

\begin{tabular}{|c|c|c|c|}
\hline$A u-C(1)$ & $2.036(4)$ & S-P & $2.0204(14)$ \\
\hline $\mathrm{Au}-\mathrm{C}(11)$ & $2.039(4)$ & $P-C(21)$ & $1.782(4)$ \\
\hline Au-N & 2.055(4) & $C(21)-C(26)$ & $1.417(5)$ \\
\hline Au-S & $2.3666(10)$ & $\mathrm{C}(26)-\mathrm{N}$ & $1.358(6)$ \\
\hline$C(1)-A u-C(11)$ & $89.00(16)$ & P-S-Au & $96.55(5)$ \\
\hline$C(1)-A u-N$ & 176.44(16) & $C(21)-P-S$ & 111.12(13) \\
\hline C(11)-Au-N & $87.48(16)$ & $C(26)-C(21)-P$ & 118.2(3) \\
\hline C(1)-Au-S & $85.44(11)$ & $\mathrm{N}-\mathrm{C}(26)-\mathrm{C} 21$ & $122.6(4)$ \\
\hline C(11)-Au-S & 174.11(11) & $\mathrm{C}(26)-\mathrm{N}-\mathrm{Au}$ & $129.9(3)$ \\
\hline N-Au-S & 98.09(12) & & \\
\hline
\end{tabular}

case of the $\mathrm{Au}$ 'I'/Au' complex $\mathbf{3}$ all the fluorine atoms appear as non equivalent, which seems to indicate that the rotation on the $\mathrm{Au}-\mathrm{C}$ bond is somehow restricted. Finally, the peak due to the molecular cation is observed in the mass spectra (ES+) of $\mathbf{4}$ at $m / z=1209$ as the base peak.

\section{Structural analysis}

In order to determine the structural differences between complexes $\mathbf{1}$ and $\mathbf{2}$, single crystals suitable for X-ray diffraction studies of both complexes were grown by slow diffusion of hexane in a solution of each complex in chloroform. Table 1 contains the data collection and refinement details, while selected bond distances and angles are shown in Tables 2 and 3 .

The structures of the metallic cation in $\mathbf{1}$ and the neutral complex $\mathbf{2}$ are very similar, displaying some differences mainly in the environment of the nitrogen atom (Figures 1 and 2). The gold atom in both complexes is bonded to two pentafluorophenyl rings and chelated by the $\mathrm{SPNH}_{2}$ or $\mathrm{SPNH}^{-}$ligand and exhibits a distorted square planar geometry. The chelating ligand is responsible for such distortion, and the $\mathrm{N}$-Au-S angle is the widest one, with a value of $98.86(14)^{\circ}(\mathbf{1})$ or $98.09(12)^{\circ}(\mathbf{2})$, while in the related derivatives of 2-(diphenylphsophino)aniline $\left[\mathrm{Au}\left(\mathrm{C}_{6} \mathrm{~F}_{5}\right)_{2}\left(\mathrm{PNH}_{2}\right)\right] \mathrm{ClO}_{4}$ and $\left[\mathrm{Au}\left(\mathrm{C}_{6} \mathrm{~F}_{5}\right)_{2}(\mathrm{PNH})\right]$ the $\mathrm{N}$-Au-P angle was always the narrowest. ${ }^{18}$ This difference is a consequence of the higher number of atoms participating in the formation of the metallocycle in complexes $\mathbf{1}$ and 2 . The Au-C distances in 2 are equal (2.036(4) and 2.039(4) $\AA)$, indicating a similar trans influence for the $\mathrm{S}$ - and $\mathrm{N}$-donor ligands present in this compound, and identical to the $\mathrm{Au}-\mathrm{C}(11)$ distance in $\mathbf{1}$ (trans to S) of 2.034(6) $\AA$, while in 1 the $\mathrm{Au}-\mathrm{C}(1)$ distance (trans to the amino group) is shorter than the rest, $(2.022(6) \AA)$, which indicates a lower trans effect for the amino group than for amido or thiophosphino groups. All these distances lie within the range of Au-C lengths found for the phosphinoamino or -amido complexes cited above (2.019(6) -2.073(7) A). ${ }^{18}$ The Au-S distances in $\mathbf{1}$ and 2, of $2.372(2)$ and 2.3666(10) $\AA$, respectively, are equal 


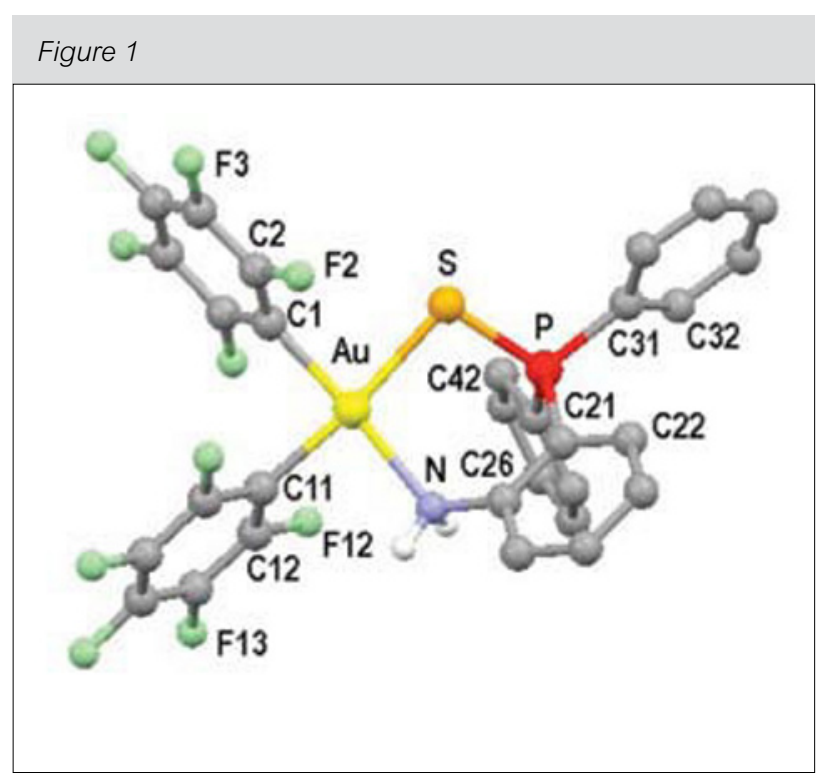

Crystal structure of the cation of complex $1 \cdot 0.5 \mathrm{CHCl}_{3}$ with the labelling scheme for the atom positions. Aromatic protons have been omitted for clarity

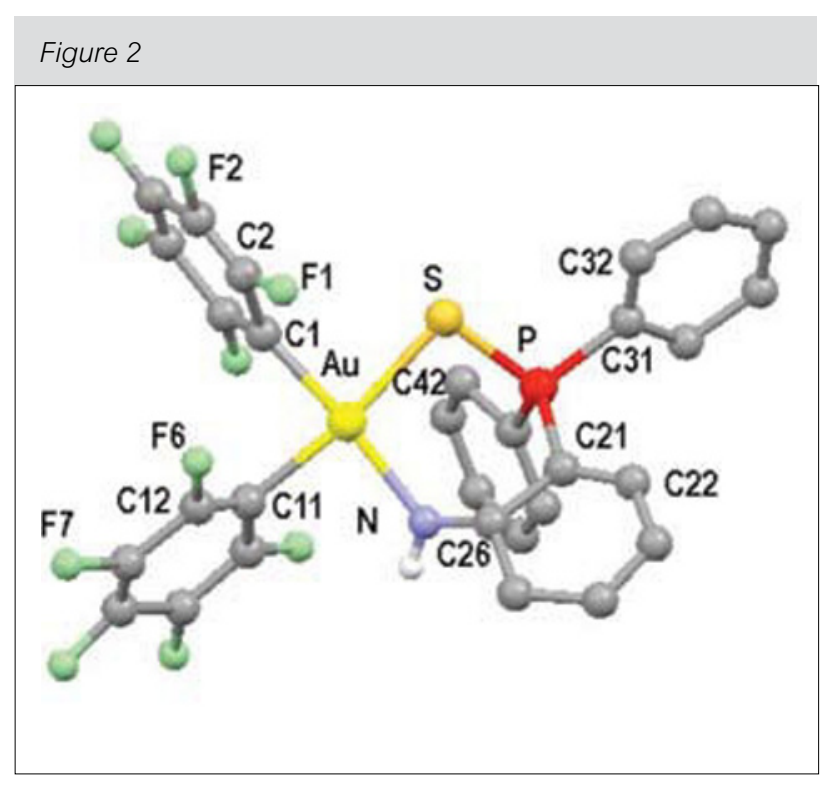

Molecular structure of complex $\mathbf{2}$ with the labelling scheme for the atom positions. Aromatic protons have been omitted for clarity

and also very close to the values found in the crystal structure of $\left[\mathrm{Au}\left(\mathrm{C}_{6} \mathrm{~F}_{5}\right)_{2} \mathrm{SSPPh}_{2} \mathrm{C}(\mathrm{AuPPh})_{2}\right)_{2} \mathrm{PPh}_{2}$ S) $\mathrm{ClO}_{4}(2.345(2) \text { and 2.390(7) } \AA)^{23}$ and intermediate between those observed in $\left[\mathrm{Au}\left(\mathrm{C}_{6} \mathrm{~F}_{5}\right)_{2}\left(\mathrm{SPPh}_{2} \mathrm{C}\right.\right.$ $\left.\left.\mathrm{HPPh}_{2}\right)\right](2.345(2) \AA)^{24}$ and in $\left[\mathrm{O}-\mathrm{C}_{6} \mathrm{H}_{4}\left\{\mathrm{NHPPh}_{2}\right.\right.$ $\left.\left.\mathrm{SAu}\left(\mathrm{C}_{6} \mathrm{~F}_{5}\right)_{3}\right\}_{2}\right](2.403(5)$ and $2.400(5) \AA) .25$ The main difference between both structures is found in the $\mathrm{Au}-\mathrm{N}$ and $\mathrm{N}-\mathrm{C}$ bond lengths of 2.157(5) and 1.448(8) $\AA$, respectively, in 1, and of 2.055(4) and 1.358(6) $\AA$, respectively, in $\mathbf{2}$. This considerable shortening of both distances in $\mathbf{2}$ is a consequence of the presence of an excess of electronic density, which is delocalized through the Au-N-C unit. Accordingly, the hybridization of the nitrogen atom changes from $\mathrm{sp}^{3}$ to $\mathrm{sp}^{2}$, which is also reflected in the $\mathrm{C}-\mathrm{N}-\mathrm{Au}$ angle, which is wider in $\mathbf{2}\left(129.9(3)^{\circ}\right)$ than in $\mathbf{1}$ $\left(121.4(4)^{\circ}\right)$, although none of them fits the expected value for each hybridization due to the distortion imposed by the formation of the six membered ring, which presents a boat conformation.

\section{Experimental}

\section{General}

$\mathrm{Ag}\left(\mathrm{OClO}_{3}\right)$ was purchased from Aldrich and used as received. The compounds 2-(diphenylphosphino)aniline $\left(\mathrm{PNH}_{2}\right),{ }^{26} \quad\left[\mathrm{Au}\left(\mathrm{C}_{6} \mathrm{~F}_{5}\right)\right.$ $\left.{ }_{2}\left(\mathrm{OEt}_{2}\right)_{2}\right] \mathrm{ClO}_{4},{ }^{27} \quad\left[\mathrm{Au}\left(\mathrm{C}_{6} \mathrm{~F}_{5}\right)_{2}(\mathrm{acac})\right],{ }^{28} \mathrm{PPN}(\mathrm{acac}),{ }^{29}$ $\left[\mathrm{Ag}\left(\mathrm{OClO}_{3}\right)\left(\mathrm{PPh}_{3}\right)\right]^{30}$ and $\left[\mathrm{Au}(\mathrm{acac})\left(\mathrm{PPh}_{3}\right)\right]^{31}$ were prepared by literature methods. 2-(diphenylthiopho sphino)aniline $\left(\mathrm{S}=\mathrm{PNH}_{2}\right)$ was prepared by reaction of $\mathrm{PNH}_{2}$ with $\mathrm{S}_{8}$ (excess) in toluene under reflux. Caution: perchlorate salts with organic cations may be explosive.

\section{Instrumentation}

Infrared spectra were recorded in the range 4000$200 \mathrm{~cm}^{-1}$ on a Perkin-Elmer FT-IR Spectrum 1000 spectrophotometer using Nujol mulls between polyethylene sheets. Conductivities were measured in ca. $5 \times 10^{-4} \mathrm{M}$ acetone solutions with a Jenway 4010 conductimeter. C, H, N analysis were carried out with a Perkin-Elmer 240C microanalyser. Mass spectra were recorded on a VG Autospec using FAB techniques and nitrobenzyl alcohol as matrix and on a HP59987 A ELECTROSPRAY. ${ }^{1} \mathrm{H},{ }^{19} \mathrm{~F}$ and ${ }^{31} \mathrm{P}\left\{{ }^{1} \mathrm{H}\right\}$ NMR spectra were recorded on a Bruker ARX 300 in $\mathrm{CDCl}_{3}$ or HDA solutions. Chemical shifts are quoted relative to $\mathrm{SiMe}_{4}\left({ }^{1} \mathrm{H}\right.$, external), $\mathrm{CFCl}_{3}\left({ }^{19} \mathrm{~F}\right.$, external) and $\mathrm{H}_{3} \mathrm{PO}_{4}(85 \%)\left({ }^{31} \mathrm{P}\right.$, external).

\section{Synthesis of $\left[\mathrm{Au}\left(\mathrm{C}_{6} \mathrm{~F}_{5}\right)_{2}\left(\mathrm{~S}=\mathrm{PNH}_{2}\right)\right] \mathrm{ClO}_{4}(1)$}

To a freshly prepared solution of $\left[\mathrm{Au}\left(\mathrm{C}_{6} \mathrm{~F}_{5}\right)_{2}\right.$ $\left(\mathrm{OEt}_{2}\right)_{2} \mathrm{ClO}_{4}(0.5 \mathrm{mmol})$ was added $\mathrm{S}=\mathrm{PNH}_{2}$ (0.5 mmol, $0.155 \mathrm{~g})$, whereupon a white solid started to form. The mixture was stirred for $2 \mathrm{~h}$ to complete the precipitation of $\mathbf{1}$, which was filtered off and washed with diethyl ether. Yield: 35\%.

\section{Synthesis of $\left[\mathrm{Au}\left(\mathrm{C}_{6} \mathrm{~F}_{5}\right)_{2}(\mathrm{SPNH})\right](2)$}

This complex was obtained by two methods:

a) To a solution of $\left[\mathrm{Au}\left(\mathrm{C}_{6} \mathrm{~F}_{5}\right)_{2}(\mathrm{acac})\right](0.3 \mathrm{mmol}, 0.19$ 
g) in $20 \mathrm{~mL}$ of dichloromethane under a nitrogen atmosphere was added $\mathrm{SPNH}_{2}(0.3 \mathrm{mmol}, 0.09$ $\mathrm{g}$ ); the solution immediately turned yellow. After 30 min of stirring it was concentrated to ca. $5 \mathrm{~mL}$ and hexane $(20 \mathrm{~mL})$ was added to precipitate 2 as a yellow solid. Yield: $61 \%$.

b) To a solution of $\mathbf{1}(0.2 \mathrm{mmol}, 0.19 \mathrm{~g})$ in $20 \mathrm{~mL}$ of dichloromethane under a nitrogen atmosphere was added PPN(acac) $(0.2 \mathrm{mmol}, 0.13 \mathrm{~g})$; the solution immediately turned yellow. After stirring for 30 min the solution was evaporated and diethyl ether was added to precipitate the $\mathrm{PPNClO}_{4}$ formed, which was filtered off over celite. The resulting yellow solution was concentrated in vacuo and $20 \mathrm{~mL}$ of hexane were added to precipitate $\mathbf{2}$ as a yellow solid. Yield: 58\%.

\section{Synthesis of $\left.\left[\mathrm{Au}\left(\mathrm{C}_{6} \mathrm{~F}_{5}\right)_{2}\left\{\mathrm{SPNH}_{(\mathrm{AuPPh}}\right)\right\}\right] \mathrm{CIO}_{4}(3)$}

This complex was obtained by two methods:

a) To a solution of $2(0.2 \mathrm{mmol}, 0.17 \mathrm{~g})$ in THF under nitrogen atmosphere was added a freshly prepared solution of $\left[\mathrm{Au}\left(\mathrm{OClO}_{3}\right)\left(\mathrm{PPh}_{3}\right)\right](0.2 \mathrm{mmol})$ (obtained by addition of the equimolecular amount of $\mathrm{Ag}\left(\mathrm{OClO}_{3}\right)$ to a THF solution of $\left[\mathrm{AuCl}\left(\mathrm{PPh}_{3}\right)\right]$ under nitrogen at $0^{\circ} \mathrm{C}$ ). After 30 min of stirring the solution was concentrated in vacuo to ca. $5 \mathrm{~mL}$, and addition of diethyl ether $(20 \mathrm{~mL})$ precipitated complex $\mathbf{3}$ as a yellow solid. Yield: 53\%.

b) To a solution of $\mathbf{1}(0.2 \mathrm{mmol}, 0.19 \mathrm{~g})$ in $20 \mathrm{~mL}$ of dichloromethane under a nitrogen atmosphere was added [Au(acac) $\left.\left(\mathrm{PPh}_{3}\right)\right](0.2 \mathrm{mmol}, 0.11 \mathrm{~g})$; the solution turned yellow. After 2 hours of stirring the solution was concentrated to ca. $5 \mathrm{~mL}$ and diethyl ether added to precipitate $\mathbf{3}$ as a yellow solid. Yield: $59 \%$.

\section{Synthesis of $\left[\mathrm{Au}\left(\mathrm{C}_{6} \mathrm{~F}_{5}\right)_{2}\left\{\mathrm{SPNH}(\mathrm{AgPPh})_{3}\right\}\right] \mathrm{ClO}_{4}(4)$} To a solution of $\mathbf{2}(0.1 \mathrm{mmol}, 0.08 \mathrm{~g})$ in dichloromethane under nitrogen atmosphere was added $\left[\mathrm{Ag}\left(\mathrm{OClO}_{3}\right)\left(\mathrm{PPh}_{3}\right)\right](0.2 \mathrm{mmol}, 0.09 \mathrm{~g})$. After 1 hour of stirring the solution was concentrated in vacuo to ca. $5 \mathrm{~mL}$ and addition of diethyl ether (20 $\mathrm{mL}$ ) precipitated complex 4 as a yellow solid.

Experimental data for 1: $\Lambda_{\mathrm{M}} 69 \Omega^{-1} \mathrm{~cm}^{2} \mathrm{~mol}^{-1}$. FAB/MS: $[\mathrm{M}]^{+}$at $\mathrm{m} / \mathrm{z}=840(100 \%)$. Elemental analysis (\%) calcd. for $\mathrm{C}_{30} \mathrm{H}_{16} \mathrm{AuClF}_{10} \mathrm{NO}_{4} \mathrm{PS}$ : C, 38.34; $\mathrm{H}, 1.72$; $\mathrm{N}$, 1.49. Found: C, 37.96; $\mathrm{H}, 1.58 ; \mathrm{N}, 1.56 .{ }^{31} \mathrm{P}\left\{{ }^{1} \mathrm{H}\right\}$ $\operatorname{NMR}\left(\mathrm{CDCl}_{3}\right), \delta: 33.6(\mathrm{~s}) .{ }^{19} \mathrm{~F} \mathrm{NMR}\left(\mathrm{CDCl}_{3}\right), \delta:-120.9$ $\left(\mathrm{m}, 2 \mathrm{~F}, \mathrm{~F}_{0}\right),-152.0\left[\mathrm{t}, 1 \mathrm{~F},{ }^{3} \mathrm{~J}\left(\mathrm{~F}_{0}-\mathrm{Fp}\right)=19.8 \mathrm{~Hz}, \mathrm{Fp}\right]$, -158.8 (m, 2F, Fm), -124.6 (m, 2F, Fo), -152.9 [t, 1F, $\left.{ }^{3} J\left(F_{O}-F_{p}\right)=19.9 \mathrm{~Hz}, F_{p}\right],-159.4(m, 2 F, F m) .{ }^{1} \mathrm{H} N M R$
$\left(\mathrm{CDCl}_{3}\right), \delta: 8.03-6.80(\mathrm{~m}, 14 \mathrm{H}$, aromatic protons $)$, $5.55\left(\mathrm{~s}, 2 \mathrm{H}, \mathrm{NH}_{2}\right)$.

Experimental data for 2: $\Lambda_{\mathrm{M}} 2 \Omega^{-1} \mathrm{~cm}^{2} \mathrm{~mol}^{-1}$. Anal. Calcd for $\mathrm{C}_{30} \mathrm{H}_{15} \mathrm{AuF}_{10} \mathrm{NPS}: \mathrm{C}, 42.93 ; \mathrm{H}, 1.80 ; \mathrm{N}$, 1.67. Found: C, 43.05; $\mathrm{H}, 1.90 ; \mathrm{N}, 1.65 .{ }^{31} \mathrm{P}\left\{{ }^{1} \mathrm{H}\right\} \mathrm{NMR}$ $\left(\mathrm{CDCl}_{3}\right), \delta: 30.7$ (s). ${ }^{19} \mathrm{~F} \mathrm{NMR}\left(\mathrm{CDCl}_{3}\right), \delta:-120.9(\mathrm{~m}$, 2F, Fo), -156.3 [t, 1F, $\left.{ }^{3} J(F o-F p)=19.9 \mathrm{~Hz}, \mathrm{Fp}\right],-160.8$ (m, 2F, Fm), -122.4 (m, 2F, $\left.\mathrm{F}_{O}\right),-156.9\left[\mathrm{t}, 1 \mathrm{~F},{ }^{3} \mathrm{~J}\left(\mathrm{~F}_{O}-\mathrm{F}_{p}\right)\right.$ $=19.9 \mathrm{~Hz}, \mathrm{Fp}],-161.6(\mathrm{~m}, 2 \mathrm{~F}, \mathrm{Fm}) .{ }^{1} \mathrm{H} \mathrm{NMR}\left(\mathrm{CDCl}_{3}\right)$, $\delta: 7.80-6.50(\mathrm{~m}, 14 \mathrm{H}$, aromatic protons), $4.66(\mathrm{~s}, 1 \mathrm{H}$, $\mathrm{NH})$.

Experimental data for 3: $\Lambda_{\mathrm{M}} 67 \Omega^{-1} \mathrm{~cm}^{2} \mathrm{~mol}^{-1}$. Anal. Calcd for $\mathrm{C}_{48} \mathrm{H}_{30} \mathrm{Au}_{2} \mathrm{ClF}_{10} \mathrm{NO}_{4} \mathrm{P}_{2} \mathrm{~S}: \mathrm{C}, 41.26 ; \mathrm{H}, 2.16$; $\mathrm{N}$, 1.0. Found: $\mathrm{C}, 41.69 ; \mathrm{H}, 1.76 ; \mathrm{N}, 1.14 .{ }^{31} \mathrm{P}\left\{{ }^{1} \mathrm{H}\right\} \mathrm{NMR}$ $\left(\mathrm{CDCl}_{3}\right), \delta: 28.4\left(\mathrm{~m}, 1 \mathrm{P}, \mathrm{PPh}_{2}\right), 28.3$ (s, 1P, AuPPh $)_{3}$. ${ }^{19} \mathrm{~F} \mathrm{NMR}\left(\mathrm{CDCl}_{3}\right), \delta:-120.8(\mathrm{~m}, 1 \mathrm{~F}, \mathrm{Fo}),-120.9(\mathrm{~m}$, $\left.1 \mathrm{~F}, \mathrm{~F}_{0}\right),-153.9\left[\mathrm{t}, 1 \mathrm{~F},{ }^{3} J\left(\mathrm{~F}_{O}-\mathrm{F}_{p}\right)=19.9 \mathrm{~Hz}, \mathrm{~F}_{p}\right],-158.2$ (m, 1F, Fm), -159.8 (m, 1F, Fm), -122.4 (m, 1F, Fo), $-124.1\left(\mathrm{~m}, 1 \mathrm{~F}, \mathrm{~F}_{O}\right)-154.8\left[\mathrm{t}, 1 \mathrm{~F},{ }^{3} J\left(\mathrm{~F}_{O}-\mathrm{F}_{p}\right)=20.1 \mathrm{~Hz}\right.$, $\mathrm{Fp}],-160.0(\mathrm{~m}, 1 \mathrm{~F}, \mathrm{Fm}),-160.8(\mathrm{~m}, 1 \mathrm{~F}, \mathrm{Fm}) ;{ }^{1} \mathrm{H} \mathrm{NMR}$ $\left(\mathrm{CDCl}_{3}\right), \delta: 8.1-6.6(\mathrm{~m}, 30 \mathrm{H}$, aromatic protons plus $\mathrm{NH}$ proton).

Experimental data for 4: $\Lambda_{\mathrm{M}} 53 \Omega^{-1} \mathrm{~cm}^{2} \mathrm{~mol}^{-1}$. ES/ MS: $[\mathrm{M}]^{+}$at $\mathrm{m} / \mathrm{z}=1209$ (100\%). Anal. Calcd for: $\mathrm{C}_{48} \mathrm{H}_{30} \mathrm{AgAuClF}_{10} \mathrm{NO}_{4} \mathrm{P}_{2} \mathrm{~S}: \mathrm{C}, 43.32 ; \mathrm{H}, 2.22 ; \mathrm{N}, 1.03$. Found: C, 42.92; $\mathrm{H}, 1.81 ; \mathrm{N}, 1.05 .{ }^{31} \mathrm{P}\left\{{ }^{1} \mathrm{H}\right\} \mathrm{NMR}$ $\left(\mathrm{CDCl}_{3}, 298 \mathrm{~K}\right), \delta: 29.7\left(\mathrm{~m}, 1 \mathrm{P}, \mathrm{PPh}_{2}\right), 13.0(\mathrm{~m}, 1 \mathrm{P}$, $\left.\mathrm{AgPPh}_{3}\right) ;{ }^{31} \mathrm{P}\left\{{ }^{1} \mathrm{H}\right\}$ NMR (HDA, 223K), $\delta: 29.4(\mathrm{~m}, 1 \mathrm{P}$, $\left.\mathrm{PPh}_{2}\right), 13.0\left[2 \mathrm{~d}, 1 \mathrm{P}, J\left({ }^{109} \mathrm{Ag}-\mathrm{P}\right)=795.2 \mathrm{~Hz}, J\left({ }^{107} \mathrm{Ag}-\right.\right.$ $\left.\mathrm{P})=688.7 \mathrm{~Hz}, \mathrm{AgPPh}_{3}\right] ;{ }^{19} \mathrm{~F} \mathrm{NMR}\left(\mathrm{CDCl}_{3}\right), \delta:-120.3$ $\left(\mathrm{m}, 2 \mathrm{~F}, \mathrm{~F}_{0}\right),-155.4\left[\mathrm{t}, 1 \mathrm{~F},{ }^{3} \mathrm{~J}\left(\mathrm{~F}_{o}-\mathrm{F}_{p}\right)=20.0 \mathrm{~Hz}, \mathrm{~F}_{p}\right]$, -159.9 (m, 2F, Fm), -122.3 (m, 2F, Fo), -156.2 [t, 1F, $\left.{ }^{3} \mathrm{~J}\left(\mathrm{~F}_{O^{-}} \mathrm{F}_{p}\right)=20.0 \mathrm{~Hz}, \mathrm{~F}_{p}\right],-161.2\left(\mathrm{~m}, 2 \mathrm{~F}, \mathrm{~F}_{m}\right) ;{ }^{1} \mathrm{H} \mathrm{NMR}$ $\left(\mathrm{CDCl}_{3}\right), \delta:$ 7.9-6.7 (m, $14 \mathrm{H}$, aromatic protons), 6.16 (s, $1 \mathrm{H}, \mathrm{NH})$.

\section{Crystallography}

The crystals were mounted in inert oil on glass fibers and transferred to the cold gas stream of a Nonius Kappa CCD diffractometer equipped with an Oxford Instruments low-temperature attachment. Data were collected by monochromated Mo K $\alpha$ radiation $(\lambda=0.71073 \AA)$. Scan type $\omega$ and $\phi$. Absorption corrections: semiempirical (based on multiple scans). The structures were solved by direct methods (1) or by Patterson (2) and refined on $F^{2}$ using the program SHELXL-97.32 All non-hydrogen atoms were anisotropically refined (exception those disordered in the crystal structure of $1: 02,03,04, \mathrm{Cl} 2, \mathrm{Cl} 3, \mathrm{Cl} 4)$ 
and hydrogen atoms were included using a riding model except the hydrogen atom of the $\mathrm{NH}^{-}$group in 2, which was located in the diffraction map. Complex 1 crystallizes with half a molecule of chloroform per molecule of compound and the chlorine atoms of the solvent as well as three of the oxygen atoms of the anion are disordered over three (40:30:30) or two (50:50) positions, respectively. Further details on the data collection and refinement methods can be found in Table 1. Selected bond lengths and angles are shown in Tables 2 and 3. CCDC-750444-750445 contain the supplementary crystallographic data for this paper. These data can be obtained free of charge via www.ccdc.cam.ac.uk/conts/retrieving. html (or from the Cambridge Crystallographic Data Centre, 12 Union Road, Cambridge CB2 1EZ, UK; fax: (+44) 1223-336-033; or e-mail: deposit@ccdc. cam.ac.uk).

\section{Acknowledgment}

The D.G>I.MEC/FEDER (CTQ2007-67273-C02-02) is thanked for financial support.

\section{About the authors}

The group in the University of La Rioja is working in gold chemistry since 1979 and they have produced more than 90 scientific papers and two patents. They focus their interest not only in the synthesis of new homo- and hetero-nuclear gold Compounds, but also in the study of some properties, such as Luminescence or biomedical behaviour, and in the application of theoretical calculations. Some of them have been invited to give talks at different International Conferences or Universities in America, Asia or Europe.

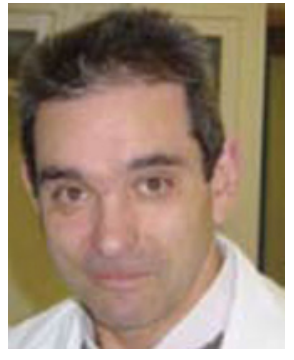

E.J. Fernández

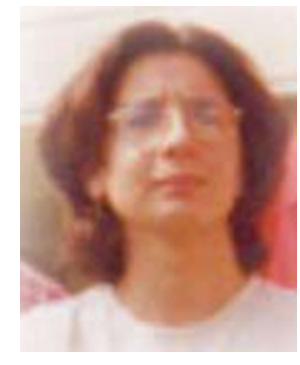

E. Garcia-Luzuriaga

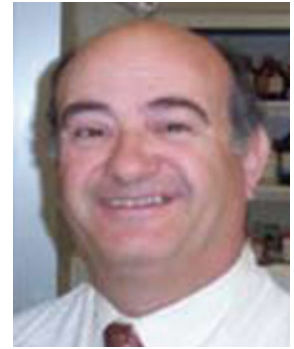

A. Laguna

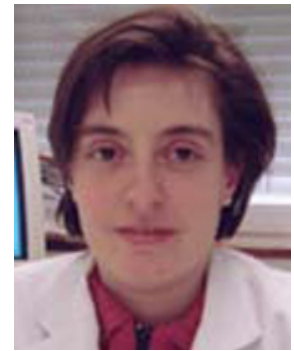

M.E. Olmos

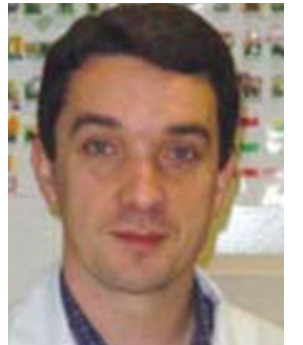

J.M. López-de-Luzuriaga

\section{References}

1 Rapson, W.S.; Groenewald, T. In Gold Usage; Academic Press: London, 1978

2 Sadler, P.J. Gold Bull. 1976, 9, 110

3 Dash, K.C.; Schmidbaur, H. In Metal lons in Biological Systems; Sigel, H., Ed.; Marcel Dekker: New York/Basel, 1982, vol. 14, p. $179 \mathrm{ff}$

4 Ulman, A. Chem. Rev. 1996, 96, 1533 and references therein

5 Shaw III, C.F. In Gold: Progress in Chemistry, Biochemistry and Technology; Schmidbaur, H., Ed.; Wiley: New York, 1999, p. $259 f f$

6 Schneider, J.; Lee, Y.A.; Perez, J.; Brennessel, W.W.; Flaschenriem, C.; Eisenberg, R. Inorg. Chem. 2008, 47, 957

7 a) Kilpin, K.J.; Henderson, W.; Nicholson, B.K. Polyhedron 2007, 26, 204. b) Kilpin, K.J.; Henderson, W.; Nicholson, B.K. Polyhedron 2007, 26, 434. c) Samantaray, M.K.; Pang, K.; Shaikh, M.M.; Ghosh, P. Inorg. Chem., 2008, 47, 4153

8 a) Redshaw, C.; Gibson, V.C.; Elsegood, M.R.J.; Clegg, W. Chem. Commun. 2007, 1951. b) Dahlenburg, L.; Herbst, K.; Liehr, G. Acta Crystallogr., Sect. C: Cryst. Struct. Commun. 1997, 53, 1545

9 a) Redshaw, C.; Gibson, V. C.; Clegg, W.; Edwards, A.J.; Miles, B.J. Chem. Soc., Dalton Trans. 1997, 3343. b) Dahlenburg, L.; Herbst, K.; Berke, H.J. Organomet. Chem. 1999, 585, 225

10 a) Bjelopavlic, M.; Duckworth, P.A.; Tiekink, E.R.T.Z. Kristallogr. 1994, 209, 626. b) Fester, V. D.; Houghton, P.J.; Main, L.; Nicholson, B.K. Polyhedron 2007, 26, 430 
11 Refosco, F.; Bolzati, C.; Tisato, F.; Bandoli, G.J. Chem. Soc., Dalton Trans. 1998, 923

12 Adams, C.J.; Bruce, M.I.; Skelton, B.W.; White, A.H. J. Organomet. Chem. 1996, 513, 255

13 Klein, H.F.; Beck, R.; Florke, U.; Haupt, H.J. Eur. J. Inorg. Chem. 2003, 240

14 a) Cooper, M.K.; Organ, G.J.; Duckworth, P.A.; Henrick, K.; McPartlin, M.J. Chem. Soc., Dalton Trans. 1988, 2287. b) Dahlenburg, L.; Herbst, K.; Zahl, A. J. Organomet. Chem. 2000, 616, 19

15 a) Wang, H.Y.; Jin, G.X. Eur. J. Inorg. Chem. 2005, 1665. b) Crociani, L.; Tisato, F.; Refosco, F.; Bandoli, G.; Corain, B. Eur. J. Inorg. Chem. 1998, 1689. c) Ansell, C.W.G.; McPartlin, M.; Tasker, P.A.; Cooper, M.K.; Duckworth, P.A. Inorg. Chim. Acta 1983, 76, L135

16 a) Reddy, K.R.; Tsai, W.W.; Surekha, K.; Lee, G.H.; Peng, S.M.; Chen, J.T.; Liu, S.T. J. Chem. Soc., Dalton Trans. 2002, 1776. b) Cooper, M.K.; Downes, J.M.; Goodwin, H.J.; McPartlin, M. Inorg. Chim. Acta 1983, 76, L155 and L155. c) Chatterjee, S.; Hockless, D.C.R.; Salem, G.; Waring, P. J. Chem. Soc., Dalton Trans. 1997, 3889. d) van den Beuken, E.K.; Meetsma, A.; Kooijman, H.; Spek, A.L., Feringa, B.L. Inorg. Chim. Acta 1997, 264, 171. e) Smith, M.B.; Slawin, A.M.Z. New. J. Chem. 2000, 24, 65. f) Bennet, J.; Doyle, R.J.; Salem, G.; Willis, A.C. Dalton Trans., 2006, 4614

17 a) Tiekink, E.R.T.; J. Coord. Chem. 1993, 28, 233. b) Slawin, A.M.Z.; Smith, M.B. New J. Chem. 1999, 23, 777. c) Crespo, O.; Fernández, E.J.; Gil, M.; Gimeno, M.C.; Jones, P.G.; Laguna, A.; López-de-Luzuriaga, J.M.; Olmos, M.E. J. Chem. Soc., Dalton Trans. 2002, 1319. d) Papathanasiou, P.; Salem, G.; Waring, P; Willis, C., J. Chem. Soc., Dalton Trans. 1997, 3435. e) Ainscough, E.W.; Brodie, A.M.; Ingham, S.L.; Waters, J.M. Inorg. Chim. Acta 1994, 217, 191. f) López-de-Luzuriaga, J.M.; Schier, A.; Schmidbaur, H. Chem. Ber. 1997, 130, 647. g) Crociani, L.; Anacardio, R.; Traldi, P.; Carain, B. Inorg. Chim. Acta 1998, 282, 119. h) Tisato, F.; Pilloni, G.; Refosco, F.; Bandolli, G.; Corvaja, C.; Corain, B. Inorg. Chim. Acta 1998, 275, 401. i) Shaw, B.L.; Iranpoor, N.; Perera, S.D.; Thornton-Pett, M.; Vessey, J.D. J. Chem. Soc., Dalton Trans. 1998, 1885. j) Slavin, A.M.Z.; Smith, M.B.N. J. Chem (Nouv. J. Chim.) 1999, 23, 777

18 Fernández, E.J.; Gil, M.; Olmos, M.E.; Crespo, O.; Laguna, A.; Jones, P.G. Inorg. Chem. 2001, 40, 3018

19 a) García Santos, I.; Hagenbach, A.; Abram, U. Dalton Trans. 2004, 677. b) Ortner, K.; Abram, U. Polyhedron
1999, 18, 749. c) Vicente, J.; Chicote, M.T.; Bermudez, M.D.; Jones, P.G.; Fittschen, C.; Sheldrick, G.M. J. Chem. Soc.; Dalton Trans. 1986, 2361. d) Parish, R.V.; Boyer, P.; Fowler, A.; Kahn, T.A.; Cross; W.I.; Pritchard, R.G. J. Chem. Soc.; Dalton Trans. 2000, 2287. e) Abram, U.; Ortner, K.; Gust, R.; Sommer, K. J. Chem. Soc.; Dalton Trans. 2000, 735. f) Abram, U.; Mack, J.; Ortner, K.; Muller, M. J. Chem. Soc.; Dalton Trans. 1998, 1011. g) Sreekanth, A.; Fun, H.K.; Kurup, M.R.P. Inorg. Chem. Commun. 2004, 7, 1250. h) Ortner, K.; Abram, U. Inorg. Chem. Commun. 1998, 1, 251. i) Tzeng, B.C.; Liu, W.H.; Liao, J.H.; Lee, G.H.; Peng, S.M. Cryst. Growth Des. 2004, 4, 573. j) Hao, L.; Lachicotte, R.J.; Gysling, H.J.; Eisenberg, R. Inorg. Chem. 1999, 38, 4616. k) Hunks, W.J.; Jennings, M.C.; Puddephatt, R.J. Inorg. Chem. 2002, 41, 4590. I) Olmos, M.E.; Schier, A.; Schmidbaur, H.Z. Naturforsch. 1997, 52b, 385

20 Hathaway, B.J.; Underhill, A.E. J. Chem. Soc. 1961, 3091

21 Usón, R.; Laguna, A.; Laguna, M.; Fernández, E.; Jones, P.G.; Sheldrick, G.M. J. Chem. Soc., Dalton Trans. 1982, 1971

22 Usón, R.; Laguna, A.; Laguna, M.; Abad, A. J. Organomet. Chem. 1983, 249, 437

23 Alvarez, B.; Fernández, E.J.; Gimeno, M.C.; Jones, P.G.; Laguna, A.; López-de-Luzuriaga, J.M. Polyhedron, 1998, 17, 2029

24 Usón, R.; Laguna, A.; Laguna, M.; Fraile, M.N.; Jones, P.G.; Erdbrügger, C.F. J. Chem. Soc., Dalton Trans. 1989, 73

25 Bella, P.A.; Crespo, O.; Fernández, E.J.; Fischer, A.K.; Jones, P.G.; Laguna, A.; López-de-Luzuriaga, J.M.; Monge, M. J. Chem. Soc., Dalton Trans. 1999, 4009

26 Cooper, M.K.; Downes, J.M.; Duckworth, P.A.; Kerby, M.C.; Powell, R.J.; Soucek, M.D. Inorg. Synth. 1989, 25, 129

27 Usón, R.; Laguna, A.; Arrese, M.L. Synth. React. Inorg. Met-Org. Chem. 1982, 1915

28 Usón, R.; Laguna, A.; Laguna, M.; Abad, A. J. Organomet. Chem. 1983, 249, 437

29 Fernández, E.J.; Gimeno, M.C.; Jones, P.G.; Laguna, A.; Laguna, M.; López de Luzuriaga, J. M. J. Chem. Soc., Dalton Trans. 1992, 3365

30 Cotton, F.A.; Falvello, L.R.; Usón, R.; Forniés, J.; Tomás, M.; Casas, J.M.; Ara, I. Inorg. Chem. 1987, 26, 1366

31 Gibson, D.; Johnson, B.F.G.; Lewis, J. J. Chem. Soc. A 1970, 367

32 Sheldrick, G.M. SHELXL-97, a program for crystal structure refinement; University of Göttingen, Germany, 1997 